\title{
K TEORIJI BREZPOSELNOSTI MLADIH
}

mag. Albert

Mrgole, asistent na Filozofski fakulteti in razvojni sodelavec na Andragoškem centru Slovenije

\section{Družbeni vidiki problematike mladinske brezposelnosti}

D

roblem mladinske brezposelnosti je čedalje večji in splošen problem sodobnih industrijskih družb, zato je pričujoči prispevek razmišljanje o nekaterih teoretskih in družbenih vidikih problematike mladinske brezposelnosti, ki jih načrtovalci izobraževalnih in drugih »interventnih « programov za mlade brezposelne ne zmeraj upoštevajo. Razmišljanje temelji na izkušnjah in raziskovalnem delu, ki ga je avtor kot sodelavec Andragoškega centra Slovenije opravil v letu $1995 / 96$ pri evalvaciji eksperimentalnega izobraževalnega programa za mlade brezposelne (Mrgole, 1996a, 1996b, 1996c in Mrgole; Žalec, 1996a, 1996b). ${ }^{1}$

\section{PROBLEM MLADINSKE BREZPOSELNOSTI}

Socialna zgodovina nas uči, da je treba $\mathrm{k}$ "success story " civilizacijskega napredka in tehničnega razvoja sodobnih industrijskih družb prišteti tudi njeno senčno plat: socialne težave nižjih slojev in povsem novo družbeno kategorijo - težave mladostnega obdobja. Tako je obdobje weimarske republike in velike gospodarske krize v Nemčiji v letih 1929-1933, ko je bila tudi med mladimi brezposelnost na vrhuncu, za mnoge mlade pomenilo izgubo upanja in njihovo odraščanje zaznamovala $\mathrm{z}$ globokim pesimizmom (Peukert, 1986; Mitterauer, 1986; Fend, 1993). Z družbeno diferenciacijo so se na novo razdelili poklici, panoge, delovna področja, različne kvalifikacije in spoli. Posamezne življenjske zgodbe so se fragmentirale, hkrati pa se je bolj razvilo konkurenčno mišljenje, začela se je desolidarizacija in povečala družbena izolacija. Theodor Geiger je leta 1932 o nemški brezposelni mladini (katere delež je znašal eno tretjino prebival- stva, kar je tedaj dejansko pomenilo 6 milijonov mladih) napisal: »... manjka jim ciljev in interesov, na katere bi se lahko sklicevali pri vključevanju v družbo.«

$\mathrm{V}$ zvezi s posledicami mladinske brezposelnosti so se znova pojavili programi tradicional-

V Sloveniji kar 30 odstotkov mladih po 15. letu starosti izpade iz šolskega sistema. nih oblik samopomoči, vendar objektivnih razmer brezposelnosti niso mogli spremeniti. Ob koncu 19. stoletja se je v tehnologiji socialne politike pojavila doktrina socialne pedagogike, ki je v opisani kaos skušala vpeljati red, poslušnost, kontinuiteto in zanesljivo načrtovanje prihodnosti, vendar je $z$ državno podporo razvila sistem, ki prav tako ni reševal položaja, marveč ga je s strategijo popolnega socialnega discipliniranja le še poslabšal (Peukert, 1986). $\mathrm{V}$ obdobju tranzicije in začetka liberalnega kapitalizma ter $\mathrm{v}$ novih razmerah na trgu delovne sile se nekako, pa naj se zdi primerjava še tako anahrona, vendarle ponavlja omenjena zgodba tudi v Sloveniji. Socialni učinki so enaki, enak je tudi delež zastopanosti brezposelnih mladih, le problematika je izražena $\mathrm{v}$ drugačnih retoričnih modalnostih. Dejstvo je, da v Sloveniji vsako leto (vsaj ${ }^{2}$ ) 30 odstotkov mladih med 15 . in 25 . letom:

- ne dokonča osnovne šole,

- ne nadaljuje šolanja po osnovni šoli,

- ali pa izpade iz nadaljevalnega šolanja.

Zaradi izpada iz šolskega sistema se mladi znajdejo pred novimi razsežnostmi družbene marginalizacije, za katero so predvsem značilne:

- brezposelnost brez možnosti za zaposlitev,

- onemogočene možnosti za dokončanje šolanja,
1 Eksperimentalni program so $s$ konceptom projekta imenovali Center za mlajše odrasle CMO, vendar se je na podlagi evalvacijske analize pokazala potreba po ustreznejšem imenu.

2 Ti statistični podatki so zbrani na način, $k i$ onemogoča izdelavo natančne podobe, posamezne kategorije se prekrivajo in niso dovolj distinktivne, da bi labko izdelali zanesljivo statistično logistiko prestopanja in migracij mladib $v$ izobraževalnem sistemu med osnounim in nadaljevalnim šolanjem. 
- družbena izolacija z zmanjšanimi možnostmi za ponovno integracijo.

\section{MLADI KOT PREDMET ANDRAGOŠKE OBRAVNAVE}

$\mathrm{Z}$ izločenostjo iz sistema rednega šolanja so se mladi znašli pred edino preostalo možnostjo: vključitev v sistem izobraževanja za odrasle. $S$ tem je andragogika postavljena pred zagato, opredeliti mora namreč svoj (novoodkriti) predmet raziskovanja in obravnavanja na dovolj distinktiven način ( $v$ prvi vrsti do pedagogike in psihologije, poleg tega pa še do drugih humanističnih ved), s katerim bi mladi postali posebna andragoška kategorija. Angleška strokovna literatura je ponudila termin "young adults«, ki ga je andragoška konceptualizacija poslovenila kot »mlajši odrasli « ter ga pri tem starostno uvrstila med 15 . in 26 . leto. $\mathrm{K}$ temu naj omenimo spremenjeno psihološko delitev, ki je prejšnje enotno pojmovanje obdobja adolescence $\mathrm{v}$ zadnjih letih notranje razdelila na:

- klasično mladost (od 15 do 19 let);

- podaljšano mladost (od 20 do 24 let: študenti in izključena mladina) in

- mlajše odrasle (od 25 do 29 let). ${ }^{3}$

Da bi se izognili nejasnostim v komunikaciji in nepotrebnim strokovnim razhajanjem, se nam zdi pomembneje opredeliti kvalitativne in vsebinske vidike obravnavane populacije $\mathrm{v}$ širšem antropološkem kontekstu. Pri našem delu je pomembno, da gre za mlade, ki so zaradi značilnega razpleta izpadli iz šolskega sistema, izgubili status dijaka in ostali v vmesnem prostoru družbene izoliranosti. $V$ sistemu izobraževanja so ti mladi, vključeni $\mathrm{v}$ izobraževanje odraslih, posebna ciljna skupina. Zato predlagamo imenovanje polja, ki opredeljuje mlade v sistemu izobraževanja odraslih, kar pomeni v nadaljevanju tudi implikacije za pripravo andragoških izobraževalnih programov.

Raziskave o mladini, ki so pri nas šele na začetku poti (Ule; Miheljak, 1995), se v Sloveniji doslej s problematiko mladinske brezposelnosti še niso sistematično ukvarjale. Iz njih (Gillis; Mitterauer; Ule, Miheljak) lahko povzamemo ugotovitev, ki poudarja stapljanje kategorije adolescence in mladosti $\mathrm{z}$ vsemi starostnimi kategorijami. Če je še Aries (1991) dokazoval, da je adolescenca odkritje moderne dobe, je Gillis opozoril, da je mladostništvo postala vsepresegajoča ideologija sodobnega časa, da se je torej adolescenca stopila $\mathrm{z}$ razlikovanjem starostnih kategorij in ni več distinktivna poteza, temveč identifikacijska določnica, ki je prepletena z vsemi starostnimi obdobji.

Mit in imaginacije o funkciji mladosti po Gillisu segajo v 18. stoletje, v obdobje revolucij, ameriške in francoske, ko se je $\mathrm{v}$ formaciji politične kulture modernih zahodnih nacionalnih držav prvič izrazila simbolna moč mladosti. Andersonova ${ }^{4}$ je idejo mladosti, ki se je pojavila mnogo prej, preden so države mlade fante organizirale $v$ vojaške oddelke, povezala $\mathrm{z}$ » imagined communities " (po Gillis, ibid.: 5). Ideja mladosti je kot distinktivna poteza začela označevati mlade države, sodobne politične vzgibe $\mathrm{v}$ nasprotju $\mathrm{z}$ rigidnimi, starimi. (Tudi Ancien Regime je $\mathrm{v}$ slovenščini preveden kot Stari režim.) Vendar sta ideologija mladosti in strah pred smrtjo mladim državam kmalu postala breme: Francija je ogrožena zaradi nizke stopnje natalitete, Amerika se je zatekla v obsesijo z mladostjo. Države, ki so svojo preteklost konstituirale kot kontinuiteto (npr. Anglija), so precej manj obremenjene s problemom staranja in starostnimi kategorijami, vendar jih je v razmerju do drugih doletela nesimpatična oznaka "old country«.

Mladost je nasprotje staranju in smrti. $\mathrm{Z}$ mitom mladih držav se je povezoval napredek, $\mathrm{ki}$ je hkrati zanikal možnost degeneracije (Pick, 1993) ali smrti. ${ }^{5} \mathrm{~V}$ monarhiji je bilo kraljevo telo edini identifikacijski objekt, po revoluciji pa sta obstajali v narodu dve telesi: starejše in mlajše. ${ }^{6}$

V predrevolucijskem času so moške mladostne skupine igrale ključno vlogo $\mathrm{v}$ ritualih skupnosti. Mladi so pomenili statistiko prihodnosti vasi, smrt in tradicija prejšnjih generacij sta bili zanje mora. Tako je bila opozicija med prihodnostjo in preteklostjo generacijsko ločena na mlade in stare, vendar je smrt pomenila del percepcije sedanjosti. Moderna kultura je izgubila prisotnost preteklosti in prihodnosti v sedanjosti (Bloch, 1989) 7 in tako sta tudi življenje in smrt postala opoziciji ter s tem mladost kot najbolj oddaljena od smrti. Vznik nacionalnih držav je predstavo skupnosti (kakor jih je opisal Marx v 18. brumairu) strukturiral na novo: prostor se je razširil, kar je ustvarilo močno ločnico med domom in tujino, med domačim in tujim. Pri tem se je razširil tudi čas in posamezniki/-ce so izgubili možnost, da bi ga suvereno nadzorovali in z njim samostojno ter svobodno upravljali. Moderne kategorije mladosti tako ne moremo misliti 
brez njenih časovno-prostorskih ideoloških pogojenosti in dinamike njene družbene konstruiranosti, na kar je zelo nazorno opozoril Bühler (1990).

Če mladost opredelimo kot ideološko kategorijo, moramo tudi mlade vsakokrat na novo opredeliti v skladu z njihovo konkretno pojavnostjo. $S$ tem namesto netenja sporov (in boja za prevladujočo opredelitev posamezne discipline) odpiramo možnosti za širše teoretske navezave.

\section{DRUŽBENI VIDIKI MARGINALIZACIJE MLADIH IN OHRANJANJA MLADINSKE BREZPOSELNOSTI}

Družbena opredelitev mladih brezposelnih je na argumentacijski lestvici (Ducrot, 1988), ki je usmerjena $\mathrm{k}$ etiologiji problematičnih, marginalnih, celo odklonskih oziroma socialno patoloških družbenih pojavov.

Ideološki vzorec mišljenja iz navedenih premis privede do navidez neproblematičnega in samoumevnega sklepa, da je mladinska brezposelnost produkt okolij nižjih družbenih razredov. Nekateri razvijajo sklepanje še naprej in $\mathrm{v}$ brezposelnih družinah $\mathrm{z}$ nižjim socialnim statusom vidijo vzrok za celotno paleto družbene odklonskosti (od brezposelnosti do kriminalitete) mladih.

Naj opozorimo na dve nevzdržni značilnosti takšnega sklepanja:

1. Najprej gre seveda za sklepanje, podprto večinoma $s$ statističnimi posplošitvami in izkrivljenjem, ki deduktivno metodo sklepanja na bistveni točki spremenijo $\mathrm{v}$ induktivno.

Mladi brezposelni po predpostavki prihajajo iz družin $\mathrm{z}$ nižjim socialnim statusom, nižjo izobrazbo staršev, večinoma je brezposelnost tudi v družini.

Opazovalec iz dela populacije izloči skupne značilnosti, identificira korelativne povezave (lastnosti, ki so značilne za socialno nižje sloje), vendar ugotovljenih lastnosti ne raziskuje naprej in ne postavi vprašanja o temeljnih vzročnih povezavah (zakaj so opisani dejavniki povezani $\mathrm{z}$ brezposelnostjo, zakaj je uživanje trših drog večinoma nadaljevanje kajenja marihuane), temveč naredi obrat in generalizacijo (ki je hkrati stigmatizacija in že nakazuje nujnost sankcioniranja in discipliniranja): vsi pripadniki socialno nižjih slojev so potencialni nosilci brezposelnosti; vsi kadilci "trave« so potencialni hudi zasvojenci z drogo. ${ }^{8}$

2. Drugo sklepanje pa izhaja iz predpostavke, da socialni status določa modus označevanja. Pri tem sodobni sociologi opozarjajo na pojav, pri katerem določeni stereotipi percepcije (ki pomenijo produkcijo in prenašanje predstav glede rase, etnicitete, spola, socialnega statusa, starosti, religije in celo fizičnega videza) vplivajo na posameznikove možnosti, da je označen (Pfohl, 1994: 361).

Kako naj torej pojmujemo družbeni kontekst mladinske brezposelnosti, ki nastane med ravnino individualnega psihičnega dogajanja in ravnino družbeno danih pričakovanj, prepričanj, predsodkov in vzgibov mentalitete določenega časa in prostora?

$\mathrm{V}$ želji, da bi identificirali odločilne prelome na poti posameznika/-ce $\mathrm{k}$ brezposelnosti, lahko sicer za nazaj odkrivamo določene dejavnike, ki pa še ve-

\section{Brezposelnost je predvsem družbeno pogojena.} dno ostajajo zavezani analitično vprašljivi deskriptivnosti, prav tako pa je vprašljiv tudi njihov vzročno pojasnjevalni pomen. Prav zaradi težavnosti in kompleksnosti pri razumevanju fenomena mladinske brezposelnosti bomo naše raziskovanje usmerili $\mathrm{k}$ nekaterim lingvistično in antropološko usmerjenim opredelitvam družbenih fenomenov normativnosti, oblikovanja družbenih vrednot, procesa socializacije, posredovanja med generacijami, družbene slojevitosti itd., ki se pojavljajo v sklopu razmerij med akterji komunikacije poklicnega vplivanja (starši, svetovalni delavci, učitelji, vrstniki, subjekti poklicnega odločanja). V tem smislu posamezne poklicne odločitve ne moremo opredeliti kot učni dosežek, ki ga lahko ugotavljamo, temveč prej kot diskurzivno tvorbo, polno diskontinuitet in nepričakovanih prelomov. $\mathrm{V}$ navedenem komunikacijskem prepletu lahko identificiramo nekaj odločilnih elementov, povezanih z naslednjima sklopoma:

1. dinamika poklicnega odločanja (dinamika želje in identifikacije),

2. dinamika poklicnih aspiracij in notranjih prepričanj posameznika/-ce o lastnih sposobnostih.

Navedena sklopa hkrati pomenita opredelitev dveh raziskovalnih področij, ki jima bomo $\mathrm{z}$ razvojem teoretskega dela $v$ nadaljevanju namenili več pozornosti. Vsekakor nas zanima, kako so ustvarjena poklicna prepričanja, kak-
8 O logiki omenjenega sklepanja prim. tudi prispevek $v$ zborniku Droge na tehtnici (1992: 193-200).

As wor 
Ljudje smo torej zmeraj v refleksivnem razmerju do svojega okolja, vedno opazujemo svoje mesto $v$ njem in ga simboliziramo, kar pa je mogoče le z jezi kom in v jeziku.

\footnotetext{
${ }^{9}$ Iz tega koncepta izhajajo vse funkcionalistične sociološke opredelitve.

${ }^{10} \mathrm{Na}$ to labko še dodatno navežemo koncept argumentativne usmerjenosti po Ducrotu.
}

šna je povezanost posameznih toposov, iz katerih posameznik/-ca silogistično sklepa in deluje v skladu s temi sklepi oziroma proti njim. Normativne, svetovalne, interpretativne, identifikacijske in druge izjave so strukturirane kot učinkovanje govorice (kot red diskurzivnosti po Foucaultu) v polju interpersonalnosti $\mathrm{z}$ neposrednimi vplivi na potek poklicnega odločanja in delovanja $\mathrm{v}$ tej smeri. Zato bomo $\mathrm{v}$ nadaljevanju skušali prikazati možnost za postavitev teoretskega razmišljanja $\mathrm{v}$ tako prikazani smeri.

Giddens (1989) uporabi jezik kot ponazorilo za nekatere vidike družbenega življenja. Pri razumevanju družbenega življenja sta najbolj pomembna koncepta produkcije in reprodukcije družbenega življenja. Kateri so torej njuni pogoji? Poenostavljena interpretacija ponuja zgodbo, v kateri mladi v procesu socializacije (bolj ali manj) postopoma sprejemajo temeljne vrednote in norme iz sveta odraslih ter tako zagotavljajo kontinuiteto dane družbene ureditve. Če hočemo razumeti bistvo družbene ureditve, ne zadostuje Parsonsov koncept ${ }^{9}$ ponotranjenja vrednot, temveč se moramo dokopati do razumevanja družbenega življenja, ki ga izvajajo akterji. To pa pomeni, da moramo razmišljati o spremenljivih razmerjih med produkcijo in reprodukcijo družbenega življenja. Ljudje moramo preoblikovati materialni svet, da bi v njem preživeli, in to je hkrati začetek procesa reprodukcije materialnih okoliščin človeškega obstoja. Vendar se na to " prisilo« ljudje ne odzivamo instinktivno, temveč kot simbolna bitja prek govorice. Jezik je poleg drugega tudi (prvo in najpomembnejše) sredstvo za človekovo praktično dejavnost (Bourdieu, 1994). Po Giddensu lahko preučujemo jezik s treh vidikov, in sicer $\mathrm{z}$ vidika individualnosti govorca - akterja, intersubjektivne komunikacije in strukture skupnosti. Jezik je zmeraj medij - sredstvo in vključuje uporabo interpretativnih shem, konstituiranje smisla, razmerja med povedanim in tistim, kar hočemo povedati, izrekanjem in izrečenim, zaznamuje ga raba različnih retoričnih figur itd. $\mathrm{V}$ tem pogledu lahko družbeno življenje opredelimo kot niz reprodukcijskih praks, ki jih lahko po zgledu delitve jezikovnih funkcij (Jakobson, 1989) prav tako preučujemo s treh vidikov:

- $z$ vidika konstituiranja kot niz dejanj, ki jih izvedejo akterji;

- kot konstitutivne oblike interakcije, ki vsebuje sporočanje pomena (pragmatično lingvistični vidik);
- kot konstitutivne strukture, ki pripadajo skupnostim (strukturirani sklopi argumentacijskih izpeljav, miselnih shem, konstruktov: verovanja, norme, rituali, ideološki mehanizmi).

Giddens (1989) govori v poglavju Produkcija komunikacije kot »smiselne « komunikacije o rabi interpretativnih shem, ki pomenijo v jeziku izraženo obliko vzajemne vednosti, s katero se $\mathrm{v}$ komunikaciji ustvarjajo in ohranjajo komunikacijski konteksti. Z drugimi besedami gre za sklope $\mathrm{v}$ trditve povezanih izjav, za ustaljene načine izpeljave njihove argumentacije, ki pomenijo skupno vednost, skupni kulturni kod ali skupno kulturno shemo določene govoreče skupnosti. V skupnih shemah so zajeta moralna pravila, normativi, vrednote, verovanja, prepričanja, predsodki itd. te skupnosti. Tako na primer vemo, da je v družbi v določenem času in prostoru delo bolj cenjeno od igre. ${ }^{10}$ Take interpretativne sheme (tipizacije) moramo razumeti kot nize splošnih pravil za dojemanje ilokucijske moči izjavam (Austin, 1990). Vzajemno znanje je zdravorazumsko, samoumevno in neartikulirano, je sklop neizrečenih, iz ozadja delujočih predpostavk - silogizmov, ki vplivajo na argumentativno usmerjenost govorca. In je torej prek nenavzočnosti - po predpostavki - ves čas navzoče $\mathrm{v}$ diskurzu, $\mathrm{v}$ interakciji, kjer ga člani skupnosti nenehno oživljajo, razkrivajo in preoblikujejo.

V komunikaciji skupnosti imajo norme kot smiselne kategorije interakcij, kot trdne reference, na katere se lahko ljudje pri oblikovanju lastnih argumentov in sklepov oprejo, eno osrednjih vlog. Giddens predlaga ločitev pojma norm in pojma pravil: normativna ali moralna pravila obravnava kot podvrsto vseobsegajočega pojmovanja pravil, povezanih $s$ pojmom strukture. Po analogiji z jezikovnim sistemom lahko rečemo, da tudi $\mathrm{v}$ družbenem sistemu vladajo pravila strukture (kot vladajo $\mathrm{v}$ jezikovnem sistemu pravila jezika, ki jih poznamo kot slovnico), moralna/normativna pravila pa so le njihov del. $S$ pojmom pravil so neposredno povezane tudi sankcije teh pravil, ki so lahko omejevalne ali dopustne. Konstituiranje interakcije po načelih moralnih pravil pomeni aktualiziranje pravic in izpolnjevanje obveznosti. Tu pa se že pojavi možnost razlike oziroma neujemanja. Drugače povedano, kar je za enega udeleženca $v$ odnosu pravica, je za drugega obveznost.

V zvezi s tem se lahko za hip neposredno dotaknemo brezposelnosti mladih in prikažemo 


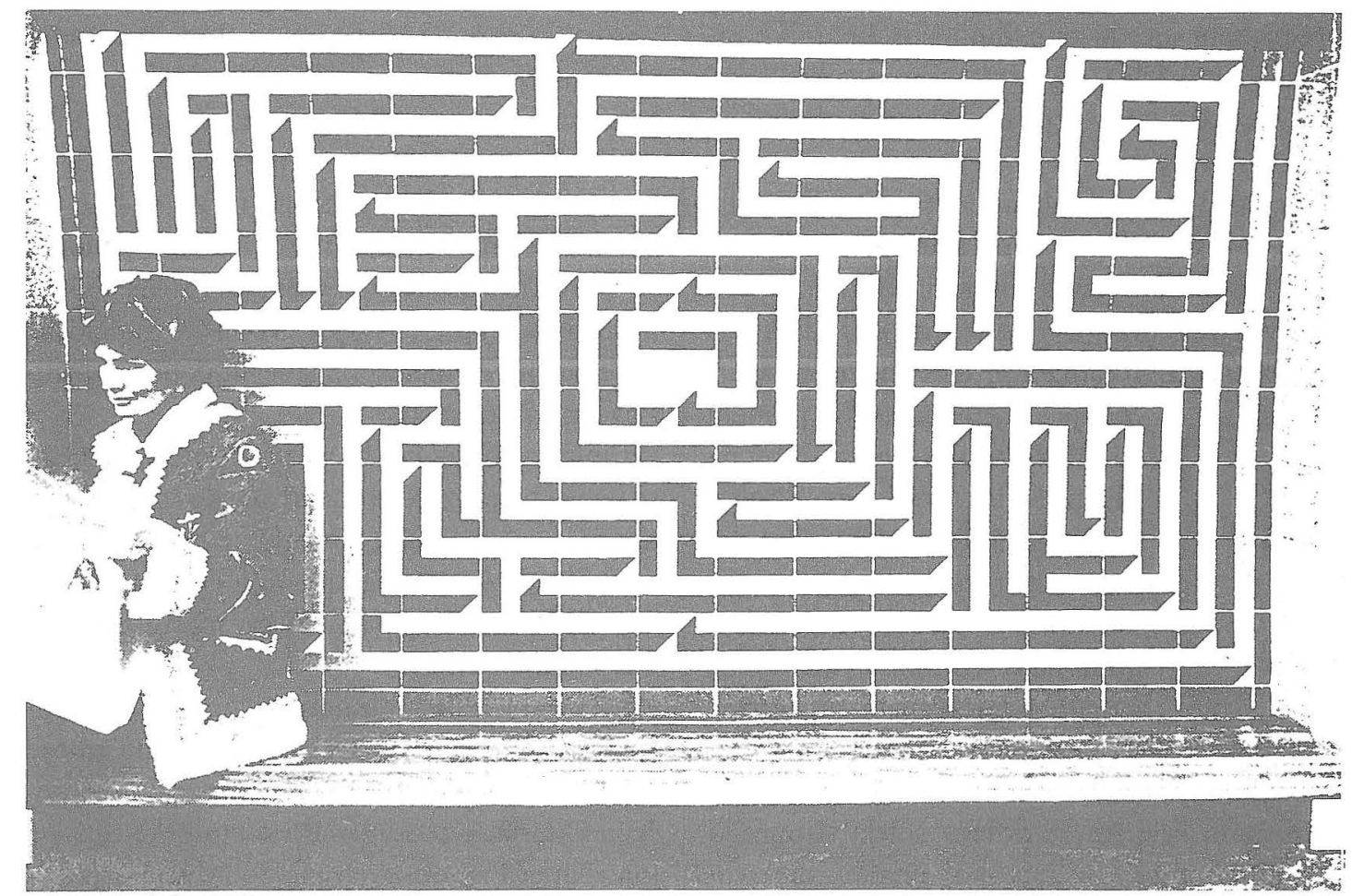

silogizem predpostavk in sankcij, ki so povezane z družbenim pomenom kategorij poklica, dela in zaposlenosti. Pojem dela je v postmoderni zahodni (kapitalistično urejeni) družbeni skupnosti, še posebej pa v deželah v tranziciji, ena temeljnih eksistencialnih obvez (Fend, 1994: 77). S pojmom dela je neposredno povezana ideološka kategorija poklica, katere zgodovinski družbeni kontekst je prikazal Weber v svoji klasični študiji (1988). Tako se zdi v naši kulturi samoumevno, da je šolanje

Nezaposlenost je sankcionirana z izgubo socialne varnosti, finančnih virov za preživetje in možnosti za aktivno participacijo na vseh drugih področjih družbenega delovanja.

namenjeno dosegu poklicne kvalifikacije, ki je temeljni pogoj za opravljanje dela in za nastop na trgu delovne sile. Izstopanje in prenehanje prakse opisanega silogizma ureja sistem družbenega sankcioniranja.

Lahko bi tudi rekli, da je ta silogizem vzorec dominantne ideologije (Althusser, 1980) dela modernih industrijskih družb. Pri evalvaciji spremljanja praktične izvedbe izobraževalnega projekta za mlade brezposelne (Mrgole, 1996c) nas je zanimalo, ali je tak argumentacijski vzorec značilen tudi za ljudi, ki so izstopili iz šolskega sistema. Predpostavili smo, da izstop iz dominantnega sistema pridobivanja poklicnih pogojev pomeni prenehanje prakticiranja vladajoče ideologije dela, vendar nas je presenetilo, da izstop iz sistema nikakor ni posledica zavestne odločitve, na podlagi katere bi mladi stopili na pot družbene marginalizacije. Poklicne in zaposlitvene želje so se v razmerah brezposelnosti še dodatno okrepile, $z$ določeno dinamiko dinamike želje med principoma ugodja in realnosti (Freud, 1987). Delo se torej pri mladih pojavlja kot kategorija, ki presega modalnost mladostniškega družbenega uporništva, in ga lahko razumemo kot močan »socializacijski « element.

" $\mathrm{V}$ produkciji interakcije moramo obravnavati vse normativne prvine kot vrsto zahtev, katerih uresničitev je odvisna od uspešne aktualizacije obveznosti s pomočjo odzivov drugih udeležencev. " (Giddens, 1989: 125) Delo spada torej v register zahtev. Uresničitev dela kot normativne zahteve družbene skupnosti pa je odvisna od tega, kako je ta zahteva aktualizirana. Drugače povedano, kako je posameznik interpeliran, nagovorjen kot $\mathrm{k}$ zahtevi dela zavezan subjekt. ${ }^{11}$

Lahko bi rekli, da se motiviranost za delovanje kaže $\mathrm{v}$ prizadevanju po sodelovanju $\mathrm{v}$ delovnem procesu, s katerim posameznik/posameznica nima neposrednih lastnih izkušenj. Gre za vidik anticipacije dela, ki bi ga posameznik/-ca želel/-a opravljati, in pri tem investira lastna prizadevanja, da bi zadostil/-a pogojem, ki so potrebni za participacijo v želenem
11 Koncept interpelacije posameznikal-ce $v$ subjekt povzemamo po Althusserju (1980). Pri tem naj pripomnimo, da ideološka interpelacija $z$ vidika posameznikal-ce poteka nazaj: lingvistične in normativne kategorije ideologije dela so že instituirane in kodificirane ter nastopajo kot determinante subjektivacije, kot jezikouni sistem, $v$ katerega se rodimo in ga moramo prevzeti, da labko splob zadostimo temelinim pogojem intersubjektivnosti.

A\& 19 
delovnem procesu. Na ravni posameznika/-ce gre pri tem seveda za psihološko dinamiko razmerja med željo, identifikacijo in subjektivacijo, procesa, ki v temelju izhaja iz dinamike nezavednega.

Tako je posameznik/-ca prek dinamike želje vpet/-a v sistem družbene normativnosti, kar vodi $\mathrm{k}$ paradoksnim konsekvencam, ki jih bomo $\mathrm{v}$ nadaljevanju raziskovalnega dela pri projektu skušali tudi empirično identificirati. ${ }^{12}$

\section{Z izgubo statusa so brezposelni oropani vseh družbenih privilegijev.}

$12 \mathrm{~V}$ mislih imamo lingvistične raziskave artikuliranosti specifičnih verovanjskih vzorcev.

13 Pripomnimo, da se je tudi Freud, ki je bistveno zaznamoval analitično paradigmo sodobnib bumanističnih disciplin, učil od Schopenhaueria, njegovi pacienti so bili prav tako "voluntersko" motivirani - celo dvakrat; najprej $z$ bolezenskim pritiskom, ki je odločilen, in dodatno s plačevanjem analize, da ne bi zapustili zdravljenja. Prav zato perspektive, $k i$ interpretacijo psiboanalitične teorije usmerijo $z$ vidika pacientov, spregledajo temeline analitične vzgibe.
Stanje brezposelnosti pomeni za mlade adolescente najprej izključitev iz socialnega okolja, ki ga zagotavljajo formalno delujoče institucije. Poleg temeljne izobraževalne dejavnosti zagotavljajo formalne institucije svojim udeležencem tudi družbeni status. Predvsem gre za dva vidika družbenega statusa, iz katerih so mladi brezposelni izključeni. Prvi status določa šolski sistem, ki podeljuje status učenca/-ke, dijaka/-inje, vajenca/-ke, študenta/-ke, in s tem posameznikom/-cam omogoča določene privilegije, povezane $s$ tem statusom (štipendije, popusti, žepnina in tolerantnost pri svobodni izrabi prostega časa $\mathrm{v}$ družini, pričakovanja in sprejetost v vrstniški skupini). Drugi status določa vključenost $\mathrm{v}$ institucijo dela in za mlade pomeni najprej samostojno pridobivanje materialnih sredstev, $s$ katerimi lahko pridobijo najrazličnejše osebne in družbene ugodnosti. Oba statusa sta družbeno pričakovana in prav družbeni pritisk (ki se kaže v izjavah okolja in domačih) je pri mladih med njihovo brezposelnostjo (ki je pri nekaterih udeležencih eksperimentalenga projekta trajala do treh let, pri večini pa le nekaj mesecev) izzval najbolj neznosno občutje družbene nekoristnosti, izoliranosti in odpora.

\section{DELO KOT DRUŽBENA NORMA}

Parsons (1949) je idejo moralnega konsenza predpostavil kot funkcinalno nujno. Drugače povedano: ideja, da lahko družba uspešno deluje le, če vsi akterji spoštujejo moralni konsenz, torej se podredijo sprejetim pravilom, je dominantna ideja vseh socializacijskih in resocializacijskih prizadevanj. Parsons je $s$ tem ustvaril verovanjski model, ki ga nekritično povzemajo predvsem pozitivistično usmerjene discipline - gre za idealizirani hipotetični konstrukt, ki na družbeno realnost ne gleda analitično, temveč funkcionalistično-idealistično.
Temu principu je zavezana tudi ekonomija vzgoje, ki si prizadeva podrediti otroka dominantnim in instituiranim normativnim pravilom in vrednotam. Parsons se ne počuti nelagodno, ko izreče totalitarno maksimo: »Če bi se vsi brez izjeme držali pravil, ne bi bilo težav.« Posameznik/-ca mora biti torej voljan sodelovati. Tako je za voluntaristične teorije od Schopenhauerja naprej volja do sodelovanja temeljni element pojasnjevanja posameznikove motiviranosti. ${ }^{13}$

Za mladostnike/-ce, ki so izstopili iz šolskega sistema, pa je značilno prav to, da v tem sistemu niso voluntaristi, da torej niso voljni sodelovati: tudi za ceno izgube določenih ugodnosti, med katerimi je na prvem mestu družabnost med vrstniki.

Prva stvar, ki jo voluntaristični miselni konstrukt spregleda (in ga pozneje tudi ne zmore notranje konsistentno misliti), je ideja delujočega akterja. Ko odpovedo sociološke razlage (na primer Parsonsove funkcionalistične razlage), se kot dobrodošlo nadomestilo ponujajo psihološke motivacijske teorije (Maslow in psihološko humanistične navezave), pri katerih se svoboda delujočega človeka zreducira le na motivacijske dispozicije posameznika/-ce. Tak sistem pa je docela determinističen: $» \mathrm{~V}$ njem ni prostora za ustvarjalne sposobnosti subjekta na ravni akterja, poglavitni vir težav pa je je razlaga izvira transformacij samih

Ekonomski sistem ni naravnan tako, da bi (hipotetično) vsi $\mathrm{z}$ dokončano izobrazbo, poklicem, ustreznimi kvalifikacijami dobili zaposlitev (to je bistvena konsekvenca konkurenčnosti na trgu delovne sile oxiroma, konsekvenca kapitalistiěnega družbenoekonomskega sistema, ki je, mimogrede rečeno, Slovenci v retoriki spreminjanja političnega sistema leta 1991 niso anticipirali).

vrednostnih standardov.« (Giddens, 1989) V tem smislu od funkcionalističnih teorij ne moremo pričakovati resne teorije resocializacije in pojasnila $\mathrm{v}$ zvezi z genezo razvoja socializacijskih sprememb, saj vrednote obravnavajo kot neproblematične danosti (Mills, 1964).

Pojasnjevalna retorika zatrjuje, da so mladi iz sistema izobraževanja izločeni po svoji krivdi, saj sami kot akterji niso izkoristili možnosti, ki jim jih je ponujal izobraževalni sistem. Vendar ne teh mladih ne tistih, ki šolanje dokončajo, ne čakajo zaposlitvene možnosti, temveč jih čaka družbeno-politično-gospodarsko do- 
ločen sistem, ki producira (in za svoj obstoj nujno predpostavlja) brezposelnost. To je tudi ena bistvenih strukturnih sprememb, ki še posebej kruto zadeva realnost mladih in njihovo zaposlitveno perspektivo $\mathrm{v}$ tako imenovanem postsocialističnem tranzicijskem obdobju.

Brezposelnost je tako argument konkurenčnosti. Vendar konkurenčnosti za tiste, ki si pridobijo izobrazbo. Zaposlovalci v tej nori dirki izpolnjujejo zahtevo (ki je seveda zakonsko podprta, torej tudi politično pravno instituira$\mathrm{na}^{14}$ ) po višje kvalificirani delovni sili, ki je niso pripravljeni sami izobraževati, temveč skušajo to nalogo podtakniti izobraževalnemu sistemu. Potreba po izobraženosti je tako implicitni motiv, ki poganja logiko izobraževanja mladih in mu pri tem pritakne še pritisk brezposelnosti. To je seveda novi družbeni kontekst, ki daje tistim, ki iz izobraževalnega sistema izstopijo, povsem nove socialne razsežnosti. Potreba po izobraženosti je poleg tega tudi implicitni motiv, ki poganja logiko pogojev za nastop na trgu delovne sile.

In kakšne so rešitve, ki se jih oprijemajo mladi? V začaranem krogu normativne paradoksnosti so na eni strani skrajno omejene družbene možnosti, določene s pogoji na trgu dela, na drugi strani pa se pojavlja normativna struktura družbenosti, ki zapoveduje "Kdor ne dela, naj ne jé «, in individualnost, ki v precepu opisane realnosti išče svojo identiteto, je takojšnja zaposlitev najlažja in edina racionalna rešitev. Takojšnja zaposlitev, ne oziraje se na nemogoče in izkoriščevalske pogoje, ki jih določijo delodajalci in pogoji na trgu delovne sile, je za brezposelne mlade hipotetična možnost, $s$ katero bodo pridobili materialna sredstva in $s$ tem razbremenili starše ter se rešili neznosnega pritiska družbene izoliranosti in označenosti (etiketiranosti). Rešitev, ki je zelo začasna, predvsem pa brezperspektivna za kontinuiteto družbe in njenih članov.

\section{LITERATURA}

Austin, John L. ([1962] 1990). Kako napravimo kaj z besedami. Ljubljana: Studia Humanitatis.

Althusser, L. et al. (1980). (Zoja Skušek Močnik, ur.). Ideologija in estetski učinek. Ljubljana: Cankarjeva založba.

Bloch, Maurice. (1989). The past and the present in the present. v: Ritual, History and Power, London: The Athlone Press.

Bourdieu, Pierre. (1994). Language and Symbolic Power. Cambridge: Polity Press.

Droge na tehtnici (1992). Časopis za kritiko znanosti XX (1992) 146-147 (tematska številka). Ljubljana.
Ducrot, Oswald. ([1984] 1988). Izrekanje in izrečeno. Ljubljana: Studia Humanitatis.

Fend, Helmut. (1994). The historical context of transition to work and youth unemployment. v: Petersen; Mortimer (ed.) (1994).

Freud, Sigmund. ([1911]1987). Formulacije o dveh načelih psihičnega delovanja. v: Metapsihološki spisi. Ljubljana: Studia humanitatis.

Frosh, Stephen. (1991). Identity Crisis. Modernity, Psychoanalysis and the Self. London: Macmillan.

Giddens, Anthony. ([1976]1989). Nova pravila sociološke metode. Ljubljana: Studia Humanitatis.

Hart, Mechthild U. (1992). Working and educating for life. (Feminist and International Perspectives on Adult Education). London and New York: Routledge.

Jakobson, Roman. (1989). Lingvistični in drugi spisi. Ljubljana: Studia Humanitatis.

Mills, C. Wright. ([1959] 1964). Sociološka imaginacija. Š(prev.) The sociological imagination]. Beograd: Savremena škola.

Mitterauer, Michael. (1986). Sozialgeschichte der Jugend. Frankfurt/M.: Suhrkamp.

Merton, Robert K. (1968). Social Theory and Social Structure. New York: The Free Press.

Mrgole, Albert. (1996a). Premagovanje izoliranosti, ki jo povzroča brezposelnost. (Izobraževanje ali sociala - novi pristopi v izobraževanju mladih brezposelnih). Delo, Priloga: Znanost za razvoj, 2. 10. 1996, str. 11.

Mrgole, Albert. (1996b). Poročilo 3. faze evalvacije eksperimentalnega projekta CMO. Ljubljana: ACS.

Mrgole, Albert. (1996c). Razvoj kurikuluma za mlajše odrasle na prehodu iz osnovnega v poklicno izobraževanje (Raziskovalno poročilo). Ljubljana: ACS.

Mrgole, Albert; Žalec, Natalija. (1996a). Poročilo 1. faze evalvacije eksperimentalnega projekta CMO. Ljubljana: ACS.

Mrgole, Albert; Žalec, Natalija. (1996b). Poročilo 2. faze evalvacije eksperimentalnega projekta CMO. Ljubljana: ACS.

Parsons, Talcott. (1949). The Structure of Social Action. New York: Free Press.

Petersen, Anne C.; Mortimer, Jeylan T. (ed.). (1994). Youth Unemployment and Society. Cambridge: Cambridge University Press.

Peukert, Detlev J. K. (1986). Grenzen der Sozialdisziplinierung. Aufsteig und Krise der deutschen Jugendfürsorge von 1878-1932. Köln: Bund Verlag.

Pfohl, Stephen. (1994). Images of Deviance and Social Control: A Sociological History. New York: McGrawHill.

Pick, Daniel. ([1989] 1993). Faces of degeneration. A European disorder, c.1848 - c.1918. Cambridge: CUP.

Ule, Mirjana. Miheljak, Vlado. (1995). Pri(e)hodnost mladine. Ljubljana: DZS.

Weber, Max. ([1947] 1988). Protestantska etika in duh kapitalizma. Ljubljana: Studia humanitatis.

${ }^{14} \mathrm{Na}$ tem mestu ne bomo začenjali razprave, kako šolski sistem s kurikularno prenovo začenja prav to igro. 